\title{
E-Resource Acquisitions in Academic Library Consortia
}

\author{
Christine N. Turner
}

Scholarly publishing is the information marketplace in which academic libraries function, and major shifts in traditional publishing and pricing models are in process. Library consortia have long been viewed as a means of increasing purchasing power and reducing costs. In late 2010, the Five College Libraries (FCL) hired $\mathrm{R} 2$ Consulting, LLC to investigate and make recommendations regarding how the Libraries cooperate more closely on the acquisition, management, and delivery of electronic resources. This study examines and evaluates how other academic library consortia are licensing and acquiring electronic books, databases, journals and streaming media. The organizations, activities, processes, history and trends of e-resource acquisitions and collection development at the Colorado Alliance of Research Libraries (CARL), Orbis Cascade Alliance (OCA), Triangle Research Libraries Network (TRLN) and Washington Research Library Consortium (WRLC) are presented with data collected by the author. Additional context is provided through a literature review, and a discussion of current practices provides a sampling of the new directions academic library consortia are taking and the challenges they face.

Christine N. Turner (cturner@library.umass .edu) is Electronic Resources Librarian, University of Massachusetts Amherst, Amherst, Massachusetts.

Submitted April 2, 2013; retuned to author with request for revision May 28, 2013; revision submitted September 20 , 2013; accepted for publication September 30, 2013.
$I^{\prime \prime}$ n the wake of the 2008 housing market collapse, rising unemployment, stock market downturn, and subsequent tightening of budgets and loss of endowment funds, the presidents and chancellor of the Five Colleges consortium institutions-Amherst College, Hampshire College, Mount Holyoke College, Smith College and the University of Massachusetts (UMass) Amherst-wrote to members in an email on April 9th, 2009, "In these difficult economic times leveraging our resources to expand the breadth of our library resources is essential." With this message, the leaders of each campus signaled their recognition of the financial need for more collaboration between the libraries in many aspects of their operations, including collection development and acquisitions.

Scholarly publishing is the information marketplace in which academic libraries function, and major shifts in traditional publishing and pricing models are in process. Library consortia have long been viewed as a means of increasing purchasing power and reducing costs. The University Leadership Council (ULC) of the Advisory Board Company (www.eab.com) identified several areas where academic libraries are applying pressure to reduce the escalating costs of scientific journals and databases in the digital realm, including pay-per-article models as an alternative to the "Big Deal" package of electronic journals bundled and 
priced based on print subscription costs, open access initiatives, and of primary concern here, "centralized purchasing authority essential in deriving savings from library consortia." Between the state-level consortia operating effectively in California (California Digital Library) and Ohio (OhioLink), and many loosely affiliated buying-clubs of libraries opting-in to discounted pricing offered by publishers based on levels of participation, consortia are striving to find ways to influence the scholarly publishing marketplace, improve access to a wider breadth of electronic resources, improve operational efficiencies, and reduce costs. Dan Hazen, associate director for collection development at Harvard University, describes current trends:

Cooperative arrangements and consortia are further reshaping the institutional environment. Economies of scale, aggregated expertise, new synergies and unexpected opportunities, and strengthened political coalitions and operational capacities are among potential benefits. Local autonomy is less possible or desirable than ever-even as institutional competition remains a hallmark of American higher education. ${ }^{2}$

The Five College Librarians Council (FCLC) recognized this challenge and set their sights on improving collaborative electronic resources licensing and management. They met with three consulting firms, and in late 2010, the Five College Libraries (FCL) hired R2 Consulting, LLC (www.ebookmap.net/index.php), which had previously worked with Smith and Mount Holyoke Colleges on technical services workflow improvements. $\mathrm{R} 2$ was asked to investigate and make recommendations on how the FCL could cooperate more closely on the management and delivery of electronic resources.

The libraries at Amherst College, Hampshire College, Mount Holyoke College, Smith College and UMass Amherst have a long history of collaboration dating back to the founding of the Five Colleges consortium in 1965. As with many academic library consortia, the early focus of activities was on resource sharing, reciprocal borrowing, a shared integrated library system, and a shared storage facility, all for print resources. In 2009, they agreed to principles and processes for avoiding unnecessary duplication of print monographs. This cooperative collection development project had a print focus when the acquisitions budgets at each library had shifted from print to electronic resources. By 2010 , nearly 70 percent of the combined budgets were dedicated to electronic resources. ${ }^{3}$

Following a study of e-resource management and delivery operations at each library and consortium-level collaboration, $\mathrm{R} 2$ proposed the creation of a shared e-content budget for e-resources purchased in common, maximizing the number of core e-resources across FCL, and negotiating more licenses at the consortium level. ${ }^{4}$ Cost savings was not a stated outcome of the proposed changes, though the recommendations were made in an economic environment of strained acquisitions budgets, as highlighted by the chancellor and presidents of the Five Colleges institutions. R2 noted that implementing their suggested changes might lead to cost benefits, but "even if more favorable pricing is not available for all these resources, the case to be made is not simply subscription savings, but operational savings and most importantly, an immensely more uniform user experience." While R2's recommendations addressed streamlining both delivery and management of common e-resource collections across FCL, the benefits and challenges of consortial collection development and acquisitions are the focus here.

The author's assumption was that FCL, while unique in some ways, was not atypical. The organization and activities of other academic library consortia, the history of collaborative collection development, the shift of acquisition monies from print to electronic materials, new complexities of pricing models and licensing, and financial pressures are relevant to libraries more broadly. To put FCL's efforts into context, this study examines how other academic library consortia are licensing and acquiring electronic books, databases, journals and streaming media. Are other consortia (as ULC and Hazen suggest is the future for academic libraries) focusing on and benefiting from economies of scale and a centralized purchasing authority? Do they offer FCL organizational and financial models for greater consortial electronic resource cooperative collection development (CCD) and acquisitions? To address these questions, the organizations, activities, processes, histories, and trends of e-resource acquisitions and collection development at the Colorado Alliance of Research Libraries (CARL), Orbis Cascade Alliance (OCA), Triangle Research Libraries Network (TRLN), and Washington Research Library Consortium (WRLC) are presented with data collected. Additional background is provided through a review of the literature and a discussion of current practices offers a sampling of the new directions academic library consortia are taking and the challenges they face.

\section{Literature Review}

\section{Library Consortia}

Cooperation has long been a tenet of libraries, and the history of library consortia and the activities in which they have engaged is well documented. Kopp traces the use of the term "library co-operation" in the literature back to the 1880s. ${ }^{6}$ Bostick names the TRLN one of the oldest academic library consortia, ${ }^{7}$ formed on the basis of a cooperative agreement signed in 1933 between the presidents 
of the University of North Carolina and Duke University. ${ }^{8}$ Alexander described the development of consortia through key events from the Great Depression, World War II, and postwar growth of higher education and scientific research to economic pressures in the $1960 \mathrm{~s}^{9}{ }^{9}$ Academic library consortia continued to form in the decades between 1931 and 1972, with the greatest growth spurt, 115 new consortia, occurring between 1961 and $1971 .{ }^{10}$ The growth and expansion of technological innovations, integrated library systems, and networked information since the 1970s brought new opportunities for library consortia. Kopp recognized another library consortial growth "resurgence" in the late 1980s and early 1990s due to a "confluence of several technological, fiscal, organizational, political and other streams." All Allen and Hirshon attributed growth of academic library consortia in the 1990s as a collaborative response to increased economic pressures from reduced state funding for public universities and tuition increases at private institutions, changes in the publishing industry, and growth of information technology. ${ }^{12}$ These economic pressures have continued to intensify.

By the 1990s, academic libraries were struggling to keep pace with burgeoning resources published in print when electronic resources were added to the mix. As electronic resources moved from standalone workstations to local area networks and then a broader networked information environment, publishers continued to introduce new products for libraries. However, many libraries found they could not afford these new products on their own. ${ }^{13}$ State funding provided a jumpstart to financing early academic library consortial database licenses. OhioLink licensed four abstracting and indexing databases in $1990 .{ }^{14}$ The Virtual Library of Virginia (VIVA) provided the first databases to its public and private academic library members in $1995 .{ }^{15}$ The Illinois Digital Academic Library (IDAL) formed in 1999 to provide resources and services to 150 public and private academic libraries in the state, including a package of EBSCOhost full-text databases. ${ }^{16}$ In 1998, OhioLink started offering the Electronic Journal Center, a collection of Big Deal e-journal packages from Elsevier, Academic Press, Kluwer Academic, Springer-Verlag, and John Wiley \& Sons available to all its membership. ${ }^{17}$

Throughout the literature on library consortia, the formation of the International Coalition of Library Consortia (ICOLC) in 1996 was recognized as a milestone in consortium development. Though a loosely affiliated and informal organization, ICOLC holds two meetings a year "dedicated to keeping participating consortia informed about new electronic information resources, pricing practices of electronic information providers and vendors, and other issues of importance to directors, governing boards, and libraries of consortia." ${ }^{18}$ ICOLC issues statements on behalf of its members to express common values and positions. Two statements of relevance to this study are the "Statement of Current
Perspective and Preferred Practices for the Selection and Purchase of Electronic Information" (March 1998), ${ }^{19}$ and the "Statement on the Global Economic Crisis and Its Impact on Consortial Licenses" (January 19, 2009; revised June 14, 2010). ${ }^{20}$ Among the points from the 1998 statement that Allen and Hirshon highlighted were higher expectations of libraries despite stable budgets, the undermining of fair use in the electronic environment, the necessity of changes to the scholarly communication system, and the unsustainable pricing practices of publishers. ${ }^{21}$ Alexander credited the creation of ICOLC with forcing publishers to take consortial purchasing groups more seriously and to negotiate with them. ${ }^{22}$ The more recent statements issued as a response to the 2008 economic crisis state a case for the serious and long-term implications to library budgets and advocate for pricing restraint, continued access to content through multiple providers, and flexibility of terms for content, contract durations, payment timetables, and opt-out and cancellations. ${ }^{23}$ From ICOLC's first meetings and a survey in 1997, Allen and Hirshon identified license negotiations and influencing pricing models for electronic resources as primary issues for library consortia. ${ }^{24}$ Perry reported in her 2009 survey of consortia that their most important issue was renegotiating licenses, followed by budget management and licensing new acquisitions. Budget management and license negotiations (both new and renewals) were projected to be the most important issues in the future. ${ }^{25}$ Priorities for consortia had not changed much since ICOLC was first formed, but they continued to be relevant. Between 2000 and 2009 membership in ICOLC increased by 56 percent ${ }^{26}$ demonstrating through sheer participation growth that the perceived value of libraries joining together to better achieve their goals remained strong. CARL, OCA, TRLN and WRLC are all ICOLC members.

Library consortia have many organizational models. Perry wrote, "Vendors and publishers are very well aware that every single consortium is unique in terms of its mission, funding sources, staffing patterns, priorities, membership, history and so forth. ${ }^{27}$ Library consortia can be organized and governed in many ways, from loosely aligned groups with no membership dues or designated staffing to highly centralized membership organizations. Perry’s 2009 survey identified a very small percentage (4.8 percent) of consortia with no paid staff and 19 percent with more than ten staff members. ${ }^{28}$ Geography, discipline (medical, law), users (public, research, liberal arts), size, funding source (private, public or both), or a combination of these factors may be the binding forces of a consortium. Allen and Hirshon group consortia into four basic types: loosely knit federation, multi-type/ multi-state network, tightly knit consortium, and centrally funded statewide consortium. These represent a continuum of local consortia with decentralized funding and staffing to centrally staffed, funded, and administered state consortia. Each type has varying degrees of local library autonomy and 
consortial flexibility, which are important attributes that contribute to a consortium achieving its goals. ${ }^{29}$

\section{Cooperative Collection Development}

The notion of libraries working together to provide more comprehensive collections of print materials than any one library could acquire alone is well established. Landesman and Van Reenan wrote the following:

Consortia are regarded as an effective strategy to increase the buying power of individual libraries over the short term and as an opportunity to maximize opportunities for cooperative collection building and for resource sharing over the long term. They offer libraries the ability to give users the access they are coming to expect and demand to a much broader range of materials than any one library could possibly offer. ${ }^{30}$

Cooperative collection development (CCD) efforts began with print resources and have evolved more recently to focus on electronic resources. Dominquez and Swindler provide a history of CCD among the TRLN libraries dating back to the 1930s and a summary of recommendations for a successful program. A key to collaborative success is building on the institution's self-interest to benefit its users with better service and broader, interdependent collections of unique and distinctive research titles. ${ }^{31}$ Other factors cited as important to a group's successful collection development efforts are common goals and a clearly articulated plan, institutional and library administration commitment and leadership, good access to bibliographic records, an effective delivery system, and effective communication and trust between administrators, faculty, and librarians. TRLN demonstrated these qualities and continues to be an innovator in CCD. It experimented with a joint approval plan for print monographs to explore, among other things, the benefits of acquiring more titles across the consortium while diverting funds from individual library approval plans to other materials. ${ }^{32}$

Fundamental to the practice of CCD in the print universe is the division between a core set of heavily used materials owned by each library and unique, less used materials purchased by selected libraries with the intention of sharing with its partners. Shreeves wrote the following:

A research library ... . will develop collections of "peripheral" material in selected areas that respond to local priorities but also serve consortial needs. This collection, in turn is backed up by the collections of consortial partners built through distributed responsibility for peripheral materials in complementary fields. ${ }^{33}$
Despite many incentives, CCD of print resources does not have a history of widespread participation. The loss of local autonomy over collection decisions, competition between higher education institutions, time required to cooperate effectively, and fear of losing acquisition budget allocations have been some of the barriers. In the past decade, research libraries have shifted their focus from CCD of prospective materials to collection management of existing materials in shared depositories. ${ }^{34}$ Ongoing demands on library spaces and budgets, as well as the shift to digital formats and the need to preserve physical materials, are bringing libraries together with a new urgency to deal with their print legacies.

CCD of electronic resources is fundamentally different from print materials in important ways. First, consortia are primarily focused on acquiring resources that are in high demand for all or multiple members, creating collections of e-resources held wholly or partially in common rather than distributing acquisitions of little-used materials among individual libraries. Shreeves notes, "Even when this is researchintensive information, the ability to provide access from anywhere makes it far more shareable than the peripheral material that was the traditional object of cooperative collection development. ${ }^{\prime 35}$ In theory, online access eliminates barriers of space and time, though in practice this accessibility has been limited by a second major difference. Publishers have required libraries to sign contracts covering terms of access before allowing connections between library users and online content. They have also sought to override fair use protections and right of first sale with license terms that restrict what libraries and their users can do with the content. Librarians have been concerned with protecting and extending use rights to the online environment, and their ability to do so has been a factor in determining whether or not a resource is suitable for acquisition. ${ }^{36}$ They have been largely successful with protecting library rights to share journal articles, but e-book content has been a different matter. Digital rights management mechanisms and contract terms have effectively undermined sharing of e-book content among consortial partners. ${ }^{37}$

\section{Acquisitions approaches}

With the emphasis consortia give to licensing negotiations and pricing models, an overview of the methods and models for acquiring electronic resources is warranted. As previously noted, beginning in the 1990s, consortia engaged with publishers to obtain access to their journal titles in various permutations, most famously the Big Deal of a collection of journals with pricing based on the print subscription costs of the combined membership plus an online access surcharge. Consortia also contracted with vendors who provided aggregations of content from various publishers in full-text 
databases. A consortium acted as a buying agent to achieve a better product price for a group of libraries than any individual library could get, as long as a minimum number of libraries participated, or a consortium purchased an electronic product to which all members had access. ${ }^{38}$ Since then, the players and methods have become increasingly complex, particularly with the advent of electronic books. Delquie and Tucker identified subscription agents, publishers, aggregators and consortia as the partners with which individual libraries can work to procure content. ${ }^{39}$ Similarly, consortia can also partner with subscription agents, publishers and aggregators to negotiate licenses on behalf of their members. The current business models are plentiful and range from leases for temporary access to outright purchases with perpetual ownership. Pay-per-view (articles) and patron driven acquisitions (e-books) enable libraries to offer users wider access to content without paying for a complete collection up front. Publishers are attracted to the potential of greater sales by putting more materials out for discovery by users. A usagebased model enables access to a collection of journals or books for a flat annual fee, with additional payment based on usage of specific titles or articles at the end of a designated period. This combines the benefits for publishers of a steady stream of income and incremental additional income, a model Joseph Esposito argues is far more palatable and cost effective for publishers than the high costs of per-unit sales. ${ }^{40}$

Some of the most dynamic arrangements are developing in agreements for e-books, and consortia are engaged in pilot projects to determine which best meet the needs and goals of their group and member libraries. TRLN has contracted with Oxford University Press (OUP) and YBP Library Services (YBP) to purchase e-books for a joint collection. ${ }^{41}$ CARL worked with EBL, ebrary, and YBP, and OCA worked with EBL and YPB for demand-driven acquisitions (DDA) of titles from multiple publishers. ${ }^{42}$ As consortia have engaged in electronic resource collection development and acquisitions over the past two decades, advantages and challenges have emerged.

\section{Advantages of Consortial E-Resource Activities}

The greatest advantage to libraries participating in consortial contracts for licensed electronic resources is that jointly they can provide access to content that many could not afford individually. Clement reported from her 2006 survey of ninety-two consortia that member ability to deliver more content to users was the greatest benefit of consortium participation. ${ }^{43}$ Seventy-one percent of Boston Library Consortium members responded to a survey that access to large publisher e-journal packages was only affordable to them through a consortial arrangement. ${ }^{44}$ OhioLink members offered their users more databases, streaming videos and audio, and e-books because of participation in the consortium. ${ }^{45}$ Kohl and Sanville made the case that the journal packages to which OhioLink subscribed provided an average of four times more titles to users at its university libraries, a twentyfold increase for four-year liberal arts colleges and an even greater increase for community colleges ${ }^{46}$ By providing access to more content, consortial libraries are giving their users more choice and selection authority through more fulltext or media content in e-journal packages and databases or through metadata for e-books. Kohl and Sanville highlighted the relative value of the collection cost/benefit ratio given the usage of titles in the OhioLink e-journal packages, especially the new titles added beyond the previously subscribed to journals. ${ }^{47}$ Consortial member libraries have paid more for the "Big Deal" e-journal packages than they did for their print subscriptions or even individual e-journal subscriptions. The trick is that they pay far less per title and have access to many more titles in the packages. Publishers have cleverly priced these packages and consortial "deals" so they receive more income by increasing participation. Individual libraries "pay to play" where they could not before and in the process spend higher percentages of their acquisitions budgets on e-resources.

Throughout the history of consortia, cost savings have been touted as a benefit of cooperative collection development, but in fact, cost sharing and containment more accurately describes the reality. Beyond achieving greater access to e-resources for less money than individual libraries would pay, consortia are valued for their ability to negotiate with content providers from a position of strength, whether for better license terms, better discounts, or lower annual price increases. Landesman and Van Reenan noted that many consortia will not deal with vendors who place limits on user access to their products. ${ }^{48}$ Several survey results recognized the benefits of consortial staff engaging in license and pricing negotiations. ${ }^{49}$

Consortia also play an advocacy role for e-resource collection development and acquisitions, as TRLN has with its "Beyond Print" project "to develop new business models and licensing terms for the cooperative acquisition of e-books" (www.trln.org/BeyondPrint) and the OCA has with its DDA pilot for e-books. These consortial initiatives are exploring new territories for CCD in the face of restrictions on e-book sharing imposed by publishers. James Brunelle of Lewis and Clark College said this of the OCA e-book pilot:

My main hope was that the project would lay the foundation for a new type of cooperative e-book collection that would be centrally funded and easily accessible by all members ... the more that e-book collections grew at the local level in individual libraries, the more we undermined the types of 
cooperative collection development projects taken on by the CDMC (OCA Collection Development and Management Committee). Building up robust, locked-down localized e-book collection is totally counterproductive and hurts the Alliance's consortial leveraging power. ${ }^{50}$

Working with publishers and vendors, consortia can bring their members and library users the benefits of more content that is also more accessible.

\section{Challenges for Consortial E-Resource Collection Development and Acquisitions}

Consortial activities on behalf of member libraries are often forged from strong relationships and conflicting demands. A commitment to participate in a consortial deal reduces a library's local autonomy and flexibility by limiting acquisition funds available for materials that best match institutional priorities or specializations. This is notably true for the Big Deal e-journal packages that often involve multiyear licenses with escalating cost commitments. ${ }^{51}$ Particularly since the 2008 financial crisis, institutional allocations for library acquisition budgets have been cut in real dollars and in relative terms because of inflationary costs of materials purchased, so the higher costs of e-resources purchased through consortia further limit local spending autonomy. Academic library consortia members confirmed these tensions between paying for their consortial e-resource commitments and maintaining budgets for their local acquisitions. Libraries may choose not to participate in new consortial deals to retain some flexibility. Perry reported that more commonly, consortia are focusing on renegotiating existing deals to derive some savings to balance their shrinking budgets. ${ }^{52}$

Another commonly cited cost of participating in consortia is that of labor, both on the part of librarians and consortium staff. Publishers and vendors prefer to deal with consortia because they can make higher dollar value sales by working with one representative group. As a result, consortium staff are bombarded with offers for products, and many have complex and varied pricing models. Westmoreland and Shirley wrote, "Consortial pricing must protect the vendors" current revenues while simultaneously developing new business. The result is often a complex price quote that lays the burden of developing equitable member cost-sharing structures on the consortium. ${ }^{, 53}$ The larger a consortium becomes, the more time staff must spend communicating, tracking, and processing acquisitions, which in turn increases overhead costs. To be thorough, publishers market the same offers, and different ones, to librarians (and often multiple librarians) at individual libraries. Library staff spend more time communicating with colleagues within their own library and the consortium about policies, offers, acceptable license terms, and technical and access issues than they do when dealing directly with a publisher or vendor. Whether e-resource products are managed by central staff or volunteers at member libraries, the workload is heavy. The South Central Academic Medical Libraries (SCAMeL) eventually formed a collection development committee to manage its collaborative e-resource purchases. Van Schaik and Moore wrote the following about SCAMeL:

Changes in personnel and structure of the Collection Development Committee happened for several reasons, but the major cause of both was the amount of work and time required to investigate new products, negotiate licenses, process renewals, communicate with membership and Board, maintain updated full-time equivalent counts and IP ranges for the consortium libraries, invoice, and plan agendas and meetings. ${ }^{54}$

These issues are compounded because libraries are frequently members of multiple consortia, each with its own mandate or area of focus. Library administrators must maintain a broad view and match the benefits and strengths of each consortium with the library's service and resource priorities, often within limited means. This can result in competition between consortia, creating difficult choices for libraries.

In addition to multiple consortia, library administrators try to balance the demands of a volatile scholarly publishing marketplace. Consortia negotiate contracts with large publishers that sell bundled content, often produced by the academic institutions themselves, for fees to support publishing and sometimes scholarly society interests. Commercial publisher interest in ever-increasing revenues often conflict with budget constraints at academic institutions. Meanwhile, academic institutions and libraries work with faculty to retain their author copyrights and support open access initiatives to make scholarly communication more affordable and accessible. Landesman and Van Reenan outlined the basic conflict:

There is an $[s i c]$ basic discongruity between consortia and new scholarly initiatives. . . Consortia and large publishers or aggregators work easily and well together; they have natural affinity. Scholarly publishing initiatives and small non-profit publishers find that they work most easily with individual libraries, librarians and faculty members. ${ }^{55}$

As more library acquisitions budgets are consumed by consortial contracts with big publishers, libraries have fewer resources, both financial and human, to support smaller, 
nonprofit publishers and experimental journals. The big publishers charging high prices tend to get more attention and promotion from libraries, crowding out the smaller scholarly publishers. Further, when publishers bundle their content, librarians are no longer selecting the highest-quality titles, but must take marginal offerings as well. Kohl and Sanville posited, "If all of a publisher's titles are purchased, the Darwinian quality of the marketplace as reflected by academic selection is defeated. An endless number of new journals could theoretically emerge without regard to academic quality or merit. ${ }^{556}$ The good news is that consortia are increasing their focus on supporting open access and scholarly communications. Perry reported from the 2009 survey of library consortia that these issues ranked in the top five of current priorities ${ }^{57}$ Nurturing academic publishing quality and open access is in the mutual interests of libraries and consortia, but juggling competing workflows is a challenge.

\section{Comparison of Target Group Consortia}

\section{Research Method}

FCL is one among many library consortia pursuing e-resource CCD and acquisitions in the scholarly publishing marketplace. The purpose of this study was to gather details about how a representative sampling of academic library consortia with similarities to the FCL license electronic resources to identify potential models for further consortial electronic resource CCD and acquisitions. The author conducted a literature and website review of academic library consortia based on the following criteria:

- number of members

- mix of types of academic institutions (liberal arts, research, etc.)

- mix of size of member institutions

- geographic proximity of members

- consortium funded through member fees (not centrally or state funded)

- types of current consortium activities

Based on these criteria and a target group of four consortia to compare with FCL, the author selected as potential subjects CARL, TRLN, OCA, and WRLC. Because of their similarities to FCL and their representation in the literature for CCD initiatives, they were judged to be good potential models. Contacts were identified from staff rosters on their websites. Including FCL, all five consortia fit Allen and Hirshon's description of a tightly knit consortium that

has some of the flexibility of the loosely knit federation, but is not encumbered by the fragmentation of membership of the multi-state, multi-type consortia. ... There is typically some dedicated staff that coordinates program development, but does not really control that program. The organization may rely solely upon institutional funding, or may supplement their [sic] resources with foundation or other external funding. The consortium may share a virtual or online union catalog . . . there is more likelihood that tightly knit federations will develop a defined and beneficial programmatic agenda over time. ${ }^{58}$

The author distributed via email sixteen open-ended questions (see appendix) covering organization, processes, and history and trends for electronic resource collection development and acquisitions to consortium directors or librarians responsible for these areas. The respondents were asked to reflect on whether they envisioned their consortium with a larger membership and a greater degree of centralization, and how their collection development and acquisitions activities had changed or might change in the future. They were asked to describe how collection development and acquisitions activities were conducted, what policies and guidelines were in place, the roles and responsibilities of consortium and member library staff, and what kinds of materials they licensed and with what access terms. The questions were designed to solicit both operational details and assessment of their e-resource acquisition programs. Related policies, statements and committee structures were collected from the consortial websites.

\section{Results}

Two consortia responded to the questions via email, one responded in a telephone interview, and the fourth provided a general response about current practices via email. The FCLC, comprising the library directors at Amherst College, Hampshire College, Mount Holyoke College, Smith College, UMass Amherst, and the executive director of Five Colleges, met with the author to discuss the questions. The author provided notes of the telephone conversation and inperson meeting (FCLC) to the participants for their review.

\section{Consortium Characteristics}

CARL (www.coalliance.org), FCL (www.fivecolleges.edu/ libraries), OCA (www.orbiscascade.org/index/index), TRLN (www.trln.org/index.htm), and WRLC (www.wrlc.org) represent a range of membership and consortial activities. All include academic libraries at both private and public institutions. CARL, with thirteen members, is the only consortium in this study that includes a public library, the Denver Public Library. FCL includes four small, private liberal arts colleges and one large, public university. TRLN is the smallest 


\begin{tabular}{|c|c|c|c|c|}
\hline Consortium & $\begin{array}{l}\text { Year } \\
\text { Founded }\end{array}$ & $\begin{array}{c}\text { \# of } \\
\text { Members }\end{array}$ & Member Types & Geographic Area \\
\hline $\begin{array}{l}\text { Five Colleges/Five College } \\
\text { Libraries }\end{array}$ & 1965 & 5 & Liberal arts college, research university & Pioneer Valley, Massachusetts \\
\hline $\begin{array}{l}\text { Triangle Research Libraries } \\
\text { Network }\end{array}$ & $1984^{*}$ & 4 & Research/university & $\begin{array}{l}\text { Chapel Hill, Durham, Raleigh, North } \\
\text { Carolina }\end{array}$ \\
\hline $\begin{array}{l}\text { Washington Research Library } \\
\text { Consortium }\end{array}$ & 1987 & 9 & Research/university & District of Columbia \\
\hline
\end{tabular}

* TRLN’s first Memorandum of Understanding was signed in 1984, though participating libraries collaborated back to the 1930s.

with four members, which are all universities. OCA has the largest membership (thirty-seven libraries), covers the largest geographical area, and represents community colleges, colleges and universities of varying sizes. WRLC has nine members, all private universities with the exception of the public George Mason University and the University of the District of Columbia. Table 1 shows the number of members, year founded, type of members, and geographic areas of each consortium.

CARL was formed in 1974 and is governed by bylaws and a board of directors with representatives from each of the thirteen member institutions (all four University of Colorado campuses share one representative). Each member signed a memorandum of understanding (MOU) authorizing CARL to do business on its behalf, and each pays a prorated fee as assessed by the board of directors. Library directors at each member campus form the member council, which is the working committee of CARL and advises the board of directors. The executive director is the managing director of eight consortium staff who cover four major programmatic areas: the Prospector union catalog, the Gold Rush Electronic Resource Management System, the Alliance Digital Repository, and database licensing.

The FCL is one of the programmatic areas within Five Colleges, incorporated in 1965. Five Colleges has an executive director who serves on the board of directors with the four college presidents, the UMass Amherst chancellor and the UMass System president. The budget is funded by institutional assessments in equal shares, grants, two endowments, and other institutional arrangements. The FCLC, consisting of the library directors at each member library and the Five Colleges executive director, manages the FCL budget and coordinates library working committees and task forces. Current FCL projects include a shared integrated library system, a reciprocal borrowing program, and a shared depository. The shared library system coordinator and depository staff positions are funded by the Five Colleges library budget.

The OCA is a result of the 2003 merger of two consortia originally founded in the 1990s: the Orbis Consortium (state and private colleges in Oregon and private and community colleges in Washington) and the Cascade Consortium (six publicly funded universities in Washington). A MOU was signed by the attorney generals of both Oregon and Washington to form the OCA as an entity of the University of Oregon. In 2011, the OCA was incorporated as a nonprofit 501(c)(3) organization. Its thirty-seven full members operate according to bylaws and a MOU. OCA business is overseen by the members council, and each full member has voting representation on it. The executive director is an ex officio member. The council votes for representatives on the board of directors. OCA programs and services are funded by member fees and other sources, as expressed in its financial framework. ${ }^{59}$ OCA's current strategic agenda covers CCD, including a print depository; a shared integrated library system; collaborative technical services; digital initiatives, including a digital archive; and a discovery system. ${ }^{60}$ A staff of seven, reporting to an executive director, supports these efforts.

Of the consortia studied, TRLN has the longest history of collaborative activity, dating back to $1933 .{ }^{61}$ The four members signed a MOU, and TRLN has a governing board consisting of the provosts and library directors from the four universities and the executive director. The organization has a staff of five to support its goals, and they report to the executive director. According to the "TRLN Principles of Cooperation," member libraries "are committed to the development of a comprehensive shared collection and integrated discovery services that are available to all students, faculty and staff at each institution." ${ }^{\prime 2}$ TRLN activities are funded by membership dues and grants, and each library contributes local funding for cooperative purchases and other TRLN programs. Aside from collaborative collection 


\begin{tabular}{|c|c|c|c|}
\hline Consortium & Governance & Funding & General Activities \\
\hline $\begin{array}{l}\text { Colorado Alliance of } \\
\text { Research Libraries }\end{array}$ & $\begin{array}{l}\text { Memoranda of understanding, } \\
\text { governing board }\end{array}$ & Member dues & $\begin{array}{l}\text { Digital repository, e-resource management system, licens- } \\
\text { ing, resource sharing, union catalog }\end{array}$ \\
\hline $\begin{array}{l}\text { Five Colleges/Five College } \\
\text { Libraries }\end{array}$ & Incorporated, nonprofit 501(c)(3) & Member dues, grants & $\begin{array}{l}\text { Integrated library system, licensing, print depository, } \\
\text { reciprocal borrowing, resource sharing }\end{array}$ \\
\hline $\begin{array}{l}\text { Triangle Research } \\
\text { Libraries Network }\end{array}$ & $\begin{array}{l}\text { Memoranda of understanding, } \\
\text { board of directors }\end{array}$ & Member dues, grants & $\begin{array}{l}\text { Cooperative collection development, digital projects, dis- } \\
\text { covery and delivery system, licensing, reciprocal borrow- } \\
\text { ing, resource sharing }\end{array}$ \\
\hline $\begin{array}{l}\text { Washington Research } \\
\text { Library Consortium }\end{array}$ & Incorporated, nonprofit 501(c)(3) & $\begin{array}{l}\text { Member dues, service } \\
\text { Fees }\end{array}$ & $\begin{array}{l}\text { Digital repository, print depository, reciprocal borrowing, } \\
\text { resource sharing, union catalog, virtual servers }\end{array}$ \\
\hline
\end{tabular}

development in many formats, TRLN engages in "reciprocal borrowing agreements and an expedited document delivery service, technology initiatives including a shared discovery and delivery system, joint projects in the areas of digital production, access and preservation, and a variety of human resources initiatives." ${ }^{.63}$

The WRLC was incorporated as a 501(c)(3) nonprofit organization in 1987. The board of directors includes the provosts or chief information officers from member institutions and the chief financial officers of the three universities that made large contributions to the consortium's reserve fund. The library directors council oversees general operations. Each institution has signed a member's agreement. The budget is funded by member assessments that are based on institutional size and budget, as well as fees for additional services provided. An executive director manages a staff of eighteen. Current activities are focused on information technology infrastructure, including a shared catalog, institutional repository, digital collection infrastructure and virtual servers; resource sharing and reciprocal borrowing; and a shared offsite storage facility. ${ }^{64}$ Table 2 provides a summary of the governance, funding and current activities of each consortium.

\section{Organization of Collection Development and E-resource Acquisitions Activities}

Electronic resource acquisition activities within these consortia, when supported, are managed through a variety of mechanisms (see table 3). WRLC is not currently licensing electronic resources on the behalf of its members. All others have some form of collection development or management committee with representation from each member library that is generally responsible for considering and recommending joint purchases of e-resources, with the exception of TRLN. TRLN's electronic resources committee, which consists of representatives from each library, coordinates activities with subject selectors and collection development staff at each campus. This committee works under the purview of TRLN's collection council. CARL, OCA, and TRLN have designated consortia staff who support e-resource acquisitions. These consortium staff positions are funded by member dues. FCL does not have dedicated consortium staff but uses the Shared Electronic Resources Management Committee (ShERM) to coordinate the licensing, implementation, and evaluation and renewal activities for the databases it acquires jointly. ShERM has representation from each library, and the Five College Libraries integrated library system coordinator chairs the group.

Member libraries of all the five consortia in this study also license electronic resources through other consortia or buying clubs and determine which offers to pursue on the basis of price and terms. Carolina Consortia, Colorado Library Consortium, Greater Western Library Alliance (GWLA), LYRASIS, Northeast Research Libraries (NERL), Oberlin Group, and Westchester Academic Library Directors Organization (WALDO) are some of groups mentioned with whom member libraries work for e-resource acquisitions. Conversely, OCA represents nonmember libraries who want to participate in an e-resource product deal, and they pay a fee for the service in addition to the shared cost of the product. ${ }^{65}$

\section{Processes}

Acquiring electronic resources with a variety of access models for a community of libraries involves many parties who perform numerous discrete and interrelated functions. The consortial contacts in this study described different ways a joint database, e-journal package, or e-book purchase may be initiated. Librarians at member libraries within CARL, FCL, OCA and TRLN suggest resources to their 
Table 3. Consortium Organization for Electronic Resources Activities

\begin{tabular}{|c|c|c|c|c|}
\hline Consortium & $\begin{array}{l}\text { E-resource/ Collection } \\
\text { Development Coordinating } \\
\text { Group }\end{array}$ & $\begin{array}{l}\text { Consortium Staff } \\
\text { Dedicated to } \\
\text { E-Resources }\end{array}$ & $\begin{array}{l}\text { Licensing Contact/Contract } \\
\text { Signatory }\end{array}$ & $\begin{array}{l}\text { E-Resources Currently } \\
\text { Acquired }\end{array}$ \\
\hline $\begin{array}{l}\text { Colorado Alliance of } \\
\text { Research Libraries }\end{array}$ & $\begin{array}{l}\text { Shared collection development } \\
\text { committee }\end{array}$ & yes & $\begin{array}{l}\text { Manager of database licensing/ } \\
\text { executive director }\end{array}$ & $\begin{array}{l}\text { Databases, e-books, e-journals, } \\
\text { reference works }\end{array}$ \\
\hline $\begin{array}{l}\text { Five Colleges/Five } \\
\text { College Libraries }\end{array}$ & $\begin{array}{l}\text { Collection management com- } \\
\text { mittee }\end{array}$ & no & $\begin{array}{l}\text { Member representative librarian } \\
\text { or executive director/executive } \\
\text { director }\end{array}$ & Databases \\
\hline $\begin{array}{l}\text { Triangle Research } \\
\text { Libraries Network }\end{array}$ & Electronic resources committee & yes & $\begin{array}{l}\text { Electronic resources committee/ } \\
\text { member institutions }\end{array}$ & $\begin{array}{l}\text { Databases, e-books, e-journals, } \\
\text { reference works, protocols }\end{array}$ \\
\hline $\begin{array}{l}\text { Washington Research } \\
\text { Library Consortium }\end{array}$ & N/A & N/A & N/A & None \\
\hline
\end{tabular}

representative on the managing committee. The committee then gauges interest among the collective members. Alternatively, the committee itself may discuss offers that come to it from vendors, consortium staff (CARL, OCA) or administrators. Criteria that determine with which vendors to work start with discounted pricing and financial savings for consortium members. Availability of resources and interface (FCL), established relationship and history (OCA), and license terms (OCA and TRLN) were mentioned as other factors that influence the choice of vendor partners. TRLN has licensing principles and guidelines endorsed by the TRLN executive committee, which serve as a benchmark for the electronic resources committee. ${ }^{66}$

Price and license negotiations are handled differently among the consortia. CARL's manager of database licensing and OCA's electronic resources program manager are the positions responsible for negotiating pricing and license terms with vendors, though the executive director reviews and signs contracts for CARL. OCA's e-resources program manager conducts the initial review of a license and solicits feedback from participating libraries. At FCL, the collection management committee representative from the member library that "champions" the resource leads the price and license-term negotiations, consulting with representatives from the ShERM and the reference, instruction and outreach committee. However, in some cases, the executive director of Five Colleges spearheads negotiations if there is a price advantage to this approach, and this position is the signatory authority for Five Colleges contracts. At TRLN, members of the electronic resources committee coordinate with the appropriate parties at their institutions to negotiate terms acceptable to their libraries. TRLN cannot sign licenses on behalf of its members; each member institution ultimately signs the license for a product.

CARL, OCA, and TRLN are all currently acquiring databases, e-journal packages, and e-books (publisher packages or DDA programs) for their members. Members opt in to participate in the database and e-journal package offers based on whether the product meets their local collection needs for a cost they can support. Access models run the gamut from lease to own to pay-per-view and single user, multi-user and site access. FCL currently leases only databases on behalf of its members on an opt-in basis.

OCA and TRLN have statements about one collection for the consortium and a "comprehensive shared collection," 67 but databases and e-journals licensed by one library are not available to users at other institutions in the consortium that do not also license it. CCD and the principle of shared access to e-resources are constrained by the license terms. R2 recommended to FCL that they jointly license a core collection of shared e-resources across the member libraries but this has been largely unrealized because of the higher costs of jointly licensing resources. OCA and TRLN are working to overcome license limitations with their e-book pilot programs, which enable all member libraries and their users access to the e-books they license. However, these agreements are not "opt in" for each library; rather, participation is required.

While overhead costs of staff, facilities, etc. at CARL, OCA and TRLN are covered by member fees, acquired electronic resources are paid for separately by those libraries that participate in the agreement. The vendor sometimes charges a flat rate to the consortium, which then divides the cost according to a predetermined formula. FCL uses a tiered "elevenths" formula that weights each library's contribution; OCA uses a formula that factors a percentage flat rate, a percentage based on full-time equivalent enrollment, and a percentage based on materials budget. More often, the vendor determines what each participating library will pay on the basis of use, full-time equivalent enrollment, 
Carnegie classification, or other factors. CARL and OCA receive and pay vendor invoices, then charge each participating library its contribution. If a vendor bills TRLN directly, it will collect payments from participating libraries. FCL pays vendor invoices and then charges back to participating libraries. However, vendors usually send invoices directly to the participating TRLN and FCL libraries for payment. Underpinning all these scenarios is a presumed cost savings reaped by each library working through the group to provide access to more content than could be offered by an individual library dealing directly with the vendor.

\section{History and Trends}

Libraries have been acquiring electronic resources in different formats for about twenty years, and the roles that consortia have played in the processes have changed over time. When databases were locally mounted and then transitioned to the web, WRLC licensed electronic resources on behalf of its members, but it has since ceased providing this service. The consortium priorities shifted to information technology infrastructure, resource sharing, and offsite storage, as WRLC thought it would achieve better e-resource cost savings through larger consortia. OCA has seen its database and e-journal package license activities mature, with fewer libraries participating in new deals. License terms for these products have also become more standard, though new issues such as text mining rights continue to emerge. Most of the consortial work is currently renewals of existing database and e-journal package contracts for which pricing models continue to evolve. TRLN members also recognize greater cost benefits through larger consortia and license fewer database and e-journal packages through TRLN now than in the past. New licenses cover different products, including e-book subject collections, protocols, and reference works. CARL continues to see growth in the e-resource acquisition services it provides to its members, and it is instituting a consortial electronic resource management system (ERMS) to support the myriad tasks it performs on their behalf. FCL continues to concentrate on acquiring databases that bring benefit to as many members as possible. It has also jointly acquired bibliographic records for common collections such as Early English Books Online (EEBO) and government documents.

The consortia count a number of successes coming from their e-resource acquisitions activities. FCL and TRLN specifically noted the beneficial working relationships engendered by the consortium committees. Improved communications and workflows have positively influenced existing workflows and laid the foundation for the consortium to take advantage of new opportunities. OCA recognized the benefits of building positive relationships with vendors. CARL and OCA cited the substantial increase in dollar value of products they license for their members. CARL also noted the increase in libraries' access to reference works and e-journals because of consortium deals. TRLN and CARL named better license terms they negotiated, from e-book interlibrary loan provisions to reasonable inflation caps and cancellation allowances.

Over time, these consortia have found their niche in what e-resource acquisitions they can do best for their members. Each one is also looking at the e-book marketplace as the next frontier. CARL, OCA, and TRLN have already ventured into it; FCL and WRLC are examining options. They are all seeking ways to build on their resource-sharing and direct-borrowing activities with print monographs as the medium changes.

Experience has also brought lessons. While most of the consortia acknowledged a more stable and standardized environment now than five years ago, OCA reported that vendors seem less flexible with their offers than in the past. CARL and TRLN noted that e-resource licensing is very labor-intensive, with work required from both consortium staff and individual library staff members. TRLN has tried to use smaller teams to work out the larger deals. CARL saw the need to build communication between collection development and cataloging people earlier in the licensing process to raise awareness about access issues during implementation, before the agreement has been signed. FCL has struggled with the challenge of users' expectation of access to the same e-resources across the consortium. Addressing that expectation-for example, expanding licenses to create a larger "core" e-library as R2 had recommended-increases the cost per item and detracts further from individual library acquisitions budgets. Five College institutions are more attentive to local needs (i.e., budget) or global issues (i.e., scholarly communication) than consortium needs, thus making it more difficult to invest in shared resources. CARL also acknowledged that some libraries still pursue individual licenses for e-products before approaching the consortium to investigate a better deal for the group.

\section{Discussion}

The ULC described library consortia with central purchasing authority as one means for disrupting the current scholarly publishing model:

Most academic libraries are involved in consortial partnerships in which resource, service, and infrastructure costs may be shared. Contacts from libraries, publishers, and vendors alike reported that truly substantial savings require a greater degree of both financial and organizational centralization, as well as a larger membership (e.g., a large 
university system or an entire state) than is typical with most consortia. Many contacts are planning to share an increasing number of resources and backend systems among institutional partners soon. ${ }^{68}$

The consortia in this study share resource, service, and infrastructure costs to some degree. They have developed their shared governance and organizational structures to carry out their programmatic objectives. They have a demonstrated history of commitment and success in their different collaborative endeavors, and they have supported a wide range of programs and initiatives. These factors contribute to their consortial cultures. However, with the exception of the OCA, none have a large membership and none are centrally funded. OCA (ILS) and CARL (ERMS), the two largest consortia in the study, are actively developing common backend systems to better manage their collective resources, and both have the most active e-resource licensing programs. These two consortia are closest to approximating the ULC vision and their representatives agreed with this statement.

The consortia in this study have had successes with e-resources collection development and licensing consistent with those described in the literature: providing greater access to resources than those available to the members individually; developing stronger relationships with staff and vendors; and in some cases, influencing vendor offers and containing costs. The four consortia that are licensing e-resources break out into the two "bigs" (CARL and OCA) and the two "smalls" (FCL and TRLN) but regardless of size, each consortium has added value to its members' e-resource collections in ways that reflect its history, culture, and collection vision. For TRLN in particular, this includes a longstanding commitment to CCD. People at each of the consortia spoke to the evolution and improvement of their processes and relationships.

The challenges that these consortia face have also been previously documented: competing interests of multiple consortia, time and labor demands of functioning in a complex environment, conflict between local interests and consortium goals, and tight budgets constrained further by consortium commitments. FCL has among its members one large research library and four small liberal arts colleges, and while the research library historically and geographically aligns well with the four colleges for direct borrowing purposes, its electronic resource and resource sharing needs are better matched with larger consortia with other research libraries. This disparity of size and academic focus of members is unique among the consortia in this study (CARL and OCA have clusters of smaller and larger members), but it serves as an example of how individual library needs are supported by more than one consortium.

Library and consortium staff have to assess the needs of their constituencies, review and negotiate product pricing and terms of use from various publishers and vendors, consider implications to their budget, their users and other consortial commitments, and coordinate between the various internal and external partners. Contacts at CARL, OCA, and TRLN acknowledged the intensity and difficulty of this labor, and these are consortia with central staff dedicated to supporting the e-resource licensing tasks. Unlike the other consortia in this study, FCL does not have staff in common to support these efforts, but it has the fewest shared licenses. The success of the cooperative e-resource licensing programs inevitably relies on staff labor at each member library and the coordinating mechanisms each consortium has in place. Making a commitment to shared e-resources in an environment with fixed labor and acquisitions budgets means that something else cannot be done or acquired locally, unless other system efficiencies are found. FCL and TRLN share few information technology systems. If the culture of collective e-resource acquisitions is not strong, libraries are more likely to pursue their individual constituency needs first, especially when monies are not pooled. The paradox is that the tighter the budgets, the more libraries are reluctant to participate in shared deals because they consume a greater proportion of their monies, thus giving them less local flexibility. Similarly, converting to shared management systems, while potentially reaping cost savings in the long run, requires more financial investment in the short term.

The reality for the smaller consortia-FCL, TRLN, and WRLC_-is that "substantial savings" are not within their sights, at least through collaborative e-resource acquisitions and management. WRLC invests many of its collective financial resources in shared IT infrastructure but recognized its limitations and withdrew from providing licensing services to its members. TRLN targets niche e-resources not available to its members through other consortia or e-journal packages it wants to provide in common to its members while using its experience in CCD to experiment with expanding its collective e-book holdings. It is adapting its CCD approach in the e-resource environment to negotiate multiple licenses for unique materials that benefit all its members, though likely at a higher cost than purchasing one item and physically sharing it between users at other libraries, as is done with CCD for print materials. The TRLN libraries share discovery and delivery platforms, but each library maintains separate integrated library systems, e-resource management systems, OpenURL resolution services, and discovery instances. Cost savings are unlikely either from back-end system efficiencies or an increase in membership.

FCL has done less e-resource CCD than other consortia in this study, with the exception of WRLC. It has struggled to implement R2's recommendations for allocating a shared e-resources budget, maximizing the number of resources licensed in common and bringing e-resources staff together to manage them. ${ }^{69} \mathrm{R} 2$ acknowledged that cost savings might 
not be an outcome, and FCLC may have pursued more databases under a joint license for the benefit to FCL users of a common, core collection. However, the increased cost of doing so has delayed implementation of this recommendation. Though the libraries share an online catalog, each library maintains its own catalog and acquisitions records, with a few exceptions. The four colleges adopted a different discovery layer than the university; UMass Amherst participates in another, larger consortial resource-sharing program that includes a different discovery layer. Individual library and institutional initiatives continue to take precedence as each determines how it wants to influence the scholarly publishing marketplace and allocate its acquisitions and personnel budgets. UMass Amherst library staff are unionized and library staff at the four colleges are not. A culture of plenty and independence is also difficult to overcome. The Five Colleges executive director noted that it is easier to centralize financial and staff resources from the outset of consortium founding than mid-stream, especially when necessary organizational supports come from parts of existing jobs at the different libraries. ${ }^{70}$ Nevertheless, the FCLC continues to seek common ground among the member institution selfinterests and initiatives.

The state of cooperative affairs as described by the ULC and Dan Hazen, where academic libraries are bound together more completely throughout their organizations, is more a vision than a reality in the realm of shared electronic resources. The larger of the consortia studied, CARL and OCA, have had the most broad-based participation and success in cooperative e-resource acquisitions and management. OCA, the one truly large consortium examined in this study, is moving in the direction of realizing the vision by pursuing shared electronic collections and management systems. As Brunelle noted, through their e-book initiatives, OCA is experimenting with a centrally funded, core e-book collection for all its members. ${ }^{71}$ The smaller consortia seem to be giving priority to those areas less fraught with the complications of licensing and the scholarly publishing marketplace, such as shared storage facilities, digital repositories and resource sharing. TRLN is a leader in the movement to provide a core collection of e-books to all member libraries, and FCL is taking deliberate steps to provide e-book records in common for a DDA program.

Electronic resources consume more and more of acquisitions budgets, and the world of academic information is not getting any smaller. Licensing electronic resources collaboratively increases access for member libraries, but it also increases costs for smaller consortia that cannot bring economies of scale to bear. Smaller consortia members have difficult choices: increase access while also increasing consortial spending, or maintain access and individual library budget autonomy. If and how small academic library consortia and their members are transitioning to cooperatives through which they can truly take advantage of economies of scale, and the consequences if they do not, are questions for another study. A related area for further inquiry is the potential effects on the scholarly publishing marketplace of a higher percentage of library acquisition monies expended on e-resources licensed jointly.

\section{Conclusion}

University and library leaders across the country, as well as Five College campus leaders, have called for greater cooperation between libraries as a means of increasing efficiencies and reducing costs. The FCLC hired a consulting firm to identify ways that the libraries could collaborate more closely. One of the areas targeted was the acquisition and management of electronic resources. The purpose of this study was to explore if and how academic library consortia with similarities to the FCL have realized cost savings and management efficiencies through CCD and a centralized purchasing authority and licensing for e-books, databases, journals, and streaming media. The challenges of CCD with print resources have been multiplied by complicated new pricing schemes and licensing requirements of electronic resources. The demands on staff are much greater. Database and e-journal package acquisitions have stabilized, and the majority of staff work is on renewals. That said, pricing schemes continue to evolve and many renewals are not pro forma. With time and experience, consortia and library staff have improved their communication and workflows, but they have not realized labor savings.

The consortia with the most members, CARL and OCA, offer their member libraries the greatest resource cost sharing and containment. Their economies of scale produce financial benefits for their members. The smaller consortia, TRLN and FCL, are in fact paying more to provide shared access to electronic resources. Contrary to the ULC proposed means of achieving substantial savings, none of the consortia studied have truly centralized purchasing authority.

Each consortium in this study has its unique culture that will either enable or inhibit its future efforts. The scholarly publishing paradigm is shifting, and academic libraries must work with publishers and faculty in different ways. All consortia recognize the e-book marketplace as a critical mutual interest and future focus because current e-book license restrictions undermine other common and historical consortial services: direct borrowing privileges and resource sharing. Among the Five Colleges institutions, a common or coordinated approach to influencing this market has not been adopted. CARL, OCA and TRLN are making concerted efforts to shape how scholarly publishers are selling e-books, though each in its unique way. The smaller consortia are struggling with their members to commit their local financial and personnel resources, or leverage the ones they 
have, to acquire and manage e-resources in ways that deliver widespread benefits.

The complexity and volatility of the scholarly publishing marketplace, the strength of individual institutional interests, and financial constraints have created a potent brew. Only the two larger consortia surveyed, CARL and OCA, spoke of adding more members to achieve greater economies of scale, pursuing a centralized purchasing authority or sharing more back-end systems. Small academic library consortia are unlikely to see operational efficiencies and cost savings without increasing memberships and financial investments in consortial e-resource management. If their member library acquisitions budgets do not increase, they will face limitations on their renewals and new purchases. How they manage their consortial alliances, their commitments to collaborative e-resource acquisitions and management, and their roles in the broader scholarly publications environment may determine to what degree they achieve their collective goals in the future. TRLN provides FCL with one model for CCD and acquisitions of electronic resources, but this model is not consistent with the vision provided by the ULC.

\section{References and Notes}

1. University Leadership Council, Redefining the Academic Library: Managing the Migration to Digital Information Services (Washington, DC: The Advisory Board Company, 2011), $\mathrm{x}$.

2. Dan Hazen, "Rethinking Research Library Collections: A Policy Framework for Straitened Times, and Beyond," Library Resources \& Technical Services 54, no. 2 (2010): 117.

3. R2 Consulting, "Five Colleges Shared Digital CollectionsPhase One," final report, November 8, 2010.

4. Ibid., 47-48.

5. Ibid., 28.

6. James J. Kopp, "Library Consortia and Information Technology: The Past, the Present, the Promise," Information Technology \& Libraries 17, no. 1 (1998): 8.

7. Sharon L. Bostick, "The History and Development of Academic Library Consortia in the United States: An Overview," Journal of Academic Librarianship 17, no. 1 (2001): 128.

8. Patricia B. Dominguez and Luke Swindler, "Cooperative Collection Development at the Research Triangle University Libraries: A Model for the Nation," College \& Research Libraries 54, no. 6 (1993): 471.

9. Adrian W. Alexander, "Toward "The Work of Perfection," Journal of Library Administration 28, no. 2 (1999): 2-5, doi: 10.1300/J111v28n02_01.

10. Kopp, "Library Consortia and Information Technology."

11. Ibid.

12. Barbara M. Allen and Arnold Hirshon, "Hanging Together to Avoid Hanging Separately: Opportunities for Academic Libraries and Consortia," Information Technology \& Libraries 17, no.
1 (March 1998): 36-37.

13. Alexander, "Toward "The Work of Perfection," 9.

14. "The Ohio Information and Library Network-History," OhioLink, accessed January 16, 2013, www.ohiolink.edu/about/ what-is-ol.html\#history.

15. "Ten Years of VIVA," Virtual Library of Virginia, accessed January 15, 2013, www.vivalib.org/10th.html.

16. Sam Brooks and Thomas J. Dorst, "Issues Facing Academic Library Consortia and Perceptions of Members of the Illinois Digital Academic Library," portal: Libraries of the Academy 2, no. 1 (January 2002): 43-44, doi: 10.1353/pla.2002.0005.

17. Glenda A. Thornton, "Impact of Electronic Resources on Collection Development, the Roles of Librarians, and Library Consortia," Library Trends 48, no. 4 (Spring 2000): 851.

18. “About ICOLC," ICOLC: International Coalitions of Library Consortia, accessed January 16, 2013, icolc.net/about-icolc.

19. .ICOLC: International Coalitions of Library Consortia, "Statement of Current Perspective and Preferred Practices for the Selection and Purchase of Electronic Information," news release, March 1998, accessed January 16, 2013, http://legacy. icolc.net/statement.html.

20. ICOLC: International Coalitions of Library Consortia, "Revised Statement on the Global Economic Crisis and Its Impact on Consortial Licenses," news release, June 14, 2010, accessed January 19, 2012, http://icolc.net/statement/revised-statementglobal-economic-crisis-and-its-impact-consortial-licenses.

21. Allen and Hirshon, "Hanging Together to Avoid Hanging Separately," 41.

22. Alexander, "Toward "The Work of Perfection," 9.

23. ICOLC, "Revised Statement."

24. Allen and Hirshon, "Hanging Together to Avoid Hanging Separately," 41.

25. Katherine A. Perry, "Where are Library Consortia Going? Results of a 2009 Survey," Serials 22, no. 2 (July 2009): 124-25.

26. Ibid., 123.

27. Ibid.

28. Ibid., 124.

29. Allen and Hirshon, "Hanging Together to Avoid Hanging Separately," 38.

30. Margaret Landesman and Johann Van Reenan, "Consortia vs. Reform: Creating Congruence,” Journal of Electronic Publishing 6, no. 2 (December 2000), doi: 10.3998/3336451.0006.203.

31. Dominguez and Swindler, "Cooperative Collection Development at the Research Triangle University Libraries," 485-87.

32. Kim Armstrong and Bob Nardini, "Making the Common Uncommon?” Collection Management 25, no. 3 (2001): 93, doi: 10.1300/J105v25no03_07.

33. Edward Shreeves, "Is There a Future for Cooperative Collection Development in the Digital Age?" Library Trends 45, no. 3 (1997): 373-90.

34. Samuel Demas and Mary E. Miller, "Rethinking Collection Management Plans: Shaping Collective Collections for the 21st Century," Collection Management 37, no. 3-4 (2012): 170, doi: $10.1080 / 01462679.2012 .685415$. 
35. Shreeves, "Is There a Future for Cooperative Collection Development in the Digital Age?"

36. Thornton, "Impact of Electronic Resources on Collection Development," 847.

37. Sarah K. Lippincott et al., "Librarian, Publisher, and Vendor Perspectives on Consortial E-Book Purchasing: The Experience of the TRLN Beyond Print Summit," Serials Review 38 (2012): 4, doi: 10.1016/j.serrev.2011.12.003.

38. Thornton, "Impact of Electronic Resources on Collection Development," 850.

39. Emilie Delquie and Cory Tucker, "Moving Forward with Electronic Content Procurement," Against the Grain 23, no. 5 (2011): 22 .

40. Joe Esposito, "The Stubborn Persistence of the Subscription Model," accessed January 18, 2012, scholarlykitchen.sspnet. org/2011/11/15/the-stubborn-persistence-of-the-subscriptionmodel.

41. Rebecca Seger et al., "TRLN/Oxford University Press/YBP Consortial E-Books Pilot" (paper presented at the Charleston Conference, Charleston, South Carolina, November 8, 2012).

42. Michael Kelly, "Two Consortial Ebook Projects Move Deeper Into Demand-Driven Acquisitions," Library Journal, June 20, 2012, accessed June 21, 2012, www.thedigitalshift. com/2012/06/ebooks/two-consortial-ebook-projects-movingdeeper-into-data-driven-acquisitions.

43. Susanne Clement, "Skills for Effective Participation in Consortia: Preparing for Collaborating and Collaboration," Collection Management 32 (2007): 195, doi: 10.1300/J105v32n01-13.

44. Philip M. Davis, "Patterns in Electronic Journal Usage: Challenging the Composition of the Geographic Consortia," College \& Research Libraries 63, no. 6 (2002): 484.

45. Laura Kinner and Alice Crosetto, "Balancing Act for the Future: How the Academic Library Engages in Collection Development at the Local and Consortial Levels," Journal of Library Administration 49, no. 4 (2009): 427, doi: 10.1080/01930820902832561.

46. David F. Kohl and Tom Sanville, "More Bang for the Buck: Increasing the Effectiveness of Library Expenditures through Cooperation," Library Trends 54, no. 3 (Winter 2006): 402, doi: 10.1353/lib.2006.0022.

47. Ibid., 403-4.

48. Landesman and Van Reenan, "The Causes of Discongruity."

49. Kinner and Crosetto, "Balancing Act for the Future," 426; Clement, "Skills for Effective Participation in Consortia," 195; Christina Torbert, "Collaborative Journal Purchasing Today: Results of a Survey," Serials Librarian 55 no. 1-2 (2008): 175, doi: 10.1080/03615260801970857.

50. Jill Emery (contributer) and Bonnie Parks (column editor, Serials Conversations), "The Demand Driven Acquisitions Pilot Project by the Orbis Cascade Alliance: An Interview with Members of the Demand Driven Acquisitions Implementation Team," Serials Review 38, no. 2 (2012): 132-33, doi: 10.1016/j. serrev.2012.04.008.

51. Davis, "Patterns in Electronic Journal Usage," 484-85; Kinner and Crosetto, "Balancing Act for the Future," 429; Torbert, "Collaborative Journal Purchasing Today,"178.

52. Perry, "Where are Library Consortia Going?," 126.

53. Tracey Westmoreland and Beverley Shirley, "The State of Consortia: Promises to Keep," Texas Library Journal (Summer 2004): 54 .

54. JoAnn Van Schaik and Millie Moore, "Group Purchasing by a Regional Academic Medical Library Consortium: How SCAMeL Made it Work," Journal of Electronic Resources in Medical Libraries 8, no. 4 (2011): 418, accessed December 11, 2012, doi: 10.1080/15424065.2011.626353.

55. Landesman and Van Reenan, "The Causes of Discongruity."

56. Kohl and Sanville, "Impact of Electronic Resources on Collection Development, the Roles of Librarians, and Library Consortia," 401-2.

57. Perry, "Where are Library Consortia Going?" 125.

58. Allen and Hirshon, "Hanging Together to Avoid Hanging Separately," 38.

59. "Orbis Cascade Financial Framework," Orbis Cascade Alliance, accessed January 29, 2013, www.orbiscascade.org/index/ cms-filesystem-action/board/policy/financial_framework_final. docx.

60. "Orbis Cascade Strategic Agenda," Orbis Cascade Alliance, accessed January 29, 2013, www.orbiscascade.org/index/strategic-agenda.

61. "History of TRLN," Triangle Research Libraries Network, accessed January 28, 2013, www.trln.org/history/trln.htm.

62. "TRLN Principles of Cooperation," Triangle Research Libraries Network, accessed January 29, 2013, www.trln.org/about/ cooperation.htm.

63. Mona C. Couts, TRLN executive director, email to the author, October 23, 2012.

64. Bruce Hulse, "Governance description," email to the author, January 29, 2013.

65. "Orbis Cascade Electronic Resource Nonmember Purchasing Program," Orbis Cascade Alliance, accessed January 30, 2013, www.orbiscascade.org/index/er-nonmember-purchasingprogram.

66. Mona C. Couts, "Triangle Research Libraries Network, 'Licensing Principles and Guidelines,' adopted by the Executive Committee," email to the author, December 2004.

67. Orbis Cascade Alliance Collection Development and Management Committee vision statement: "As an Alliance, we consider the combined collections of member institutions as one collection. While member institutions continue to acquire their own material, the Alliance is committed to cooperative collection development to leverage member institutions' resources to better serve our users." Accessed January 31, 2013, www.orbiscascade.org/index/strategic-agenda. Triangle Research Libraries Network Principles of Cooperation: "The TRLN member libraries are committed to the development of a comprehensive shared collection and integrated discovery and delivery systems that are available to all students, faculty and staff at each institution." Accessed January 31, 2013, www.trln.org/ 
about/cooperation.htm.

68. University Leadership Council, Redefining the Academic Library: Managing the Migration to Digital Information Service (Washington, DC: The Advisory Board Company, 2011), $\mathrm{x}$.

69. R2 Consulting, "Five Colleges Shared Digital
Collections-Phase One," 44-48.

70. Five College Librarians Council, in discussion with the author, December 17, 2012.

71. Emery and Parks, "The Demand Driven Acquisitions Pilot Project by the Orbis Cascade Alliance," 132-33.

\section{Appendix. Research Questions for Academic Library Consortia}

Organization

1. Is this statement from the University Leadership Council in the 2011 publication Redefining the Academic Library: Managing the Migration of Digital Information Services true for the Colorado Alliance/Orbis Cascade Alliance/Triangle Research Library Alliance/Washington Research Library Consortium:

"Most academic libraries are involved in consortial partnerships in which resource, service, and infrastructure costs may be shared. Contacts from libraries, publishers, and vendors alike reported that truly substantial savings require a greater degree of both financial and organizational centralization, as well as a larger membership (e.g., a large university system or an entire state) than is typical with most consortia. Many contacts are planning to share an increasing number of resources and back-end systems among institutional partners in the near future." (p. x)

2. Is the Colorado Alliance/Orbis Cascade Alliance/Triangle Research Library Alliance/Washington Research Library Consortium in a position to benefit from greater financial and organizational centralization for consortium acquisition of e-resources?

3. Do, or will, your members acquire e-resources via other consortia to benefit from cost savings? If so, are these purchases for collections held in common or by individual members?

4. How are e-resource collection development activities conducted and managed across the consortium? If you have consortium staff who participate in e-resource acquisition, how are their positions funded?

5. Are e-resources acquired as core, shared resources; to improve breadth of subject access across the consortium; or both?

\section{Processes}

6. What types of e-resources (databases, e-books, e-journals, streaming media, other?) have your consortium acquired on behalf of its membership in the past 5 years?

7. What policies and procedures guide the acquisition of e-resources for the consortium?

8. What access models (lease, own, pay-per-view; single user, multi-user, site; other) have you licensed?

9. How are e-resources recommended and selected?

10. On what criteria are vendor partners selected?

11. Who reviews and negotiates licenses with vendors? Do you have standard terms and an agreement on unacceptable terms?

12. How are e-resource acquisitions funded? How are costs shared? Are invoices paid to the vendor by member libraries or the consortium?

\section{History and Trends}

13. How have e-resource acquisitions changed in your consortium in terms of organization, products and processes over the past 5 years?

14. How do you anticipate they will change in the next five years?

15. What consortium e-resource acquisition programs would you consider successful in the past 5 years, and why?

16. What lessons have you learned and how would you recommend improving future ventures from a consortium standpoint? 